Discussion Papers in Economics and Econometrics

\begin{tabular}{||l||}
\hline EFFECTS OF TARIFFS AND REAL \\
EXCHANGE RATES ON JOB \\
REALLOCATION: EVIDENCE FROM LATIN \\
AMERICA \\
John Haltiwanger \\
Adriana Kugler \\
Maurice Kugler \\
Alejandro Micco \\
Carmen Pagés \\
No. 0410 \\
\hline
\end{tabular}

This paper is available on our website http://www.socsci.soton.ac.uk/economics/Research/Discussion_Papers 


\title{
Effects of Tariffs and Real Exchange Rates on Job Reallocation: Evidence from Latin America*
}

\author{
John Haltiwanger, Adriana Kugler, Maurice Kugler, Alejandro Micco and Carmen Pagés ${ }^{* *}$
}

August 25, 2004

\begin{abstract}
Openness to international competition can lead to enhanced resource allocation in the long-run. While factor reallocation is essential if net benefits are to be derived from trade liberalization, the process generates costs both for transitioning workers and for employers undergoing personnel turnover. Net welfare gains depend on adjustment costs. Understanding of these issues has been hampered by data limitations. In this paper, we overcome some of these limitations by using new, harmonized measures on job creation and destruction for a number of countries in Latin America. We use these new series to investigate the impact of the removal of protectionism on net employment and gross job reallocation in Latin America. We find a robust pattern showing that reductions in tariffs and exchange rate appreciations increase the pace of job reallocation within sectors. We also find, however, some evidence of declining net employment as trade exposure increases. For example, we find some evidence that in the wake of tariff reductions, there is lower net employment growth.
\end{abstract}

Keywords: Tariff reduction, Currency appreciation, Trade exposure, Intra-industry reallocation JEL Classification: F160, F310, O240.

* The data used in this paper were compiled as part of the project "Market Institutions, Labor Market Dynamics, Growth and Productivity" coordinated by the authors of this paper and sponsored by the Latin American Research Network of the Research Department at the InterAmerican Development Bank. We would like to thank all participants for their contribution to constructing the harmonized database.

** Affiliations: University of Maryland, University of Houston, University of Southampton, InterAmerican Development Bank and Inter-American Development Bank. Corresponding author: John Haltiwanger, Department of Economics, University of Maryland, College Park, MD, 207427211, U.S.A. E-mail: haltiwan@econ.umd.edu 


\section{INTRODUCTION}

Assessment of the effects of trade liberalization on the reallocation of resources is essential. Reallocation is at the heart of welfare gains from openness as factor deployment becomes more efficient. Also, reallocation is at the heart of potential factor adjustment and displacement costs induced by tariff reductions. Net welfare gains result if the benefits from higher productivity exceed the costs due to factor redeployment. Inefficient firms in import competing industries exposed to tariff reductions experience lower profitability of some projects and thus contract, and in some cases are forced to shut down all production facilities. At the same time, the increased openness creates new export opportunities for other producers leading to expansion of both better positioned incumbents and new startups. Openness facilitates links required to expand into foreign markets. For example, access to technology embodied in imported equipment and machinery can yield higher productivity for those firms able to take advantage. Moreover, exposure to foreign competition generates shifts of market share among producers within tradable industries.

In addition to reallocation due to downsizing of less productive firms in favor of more productive ones, new information gets revealed after policy changes. Firms partly learn how well they adapt to the new market place after they have operating under the new conditions for some time, as with any change in the economic environment. Some firms may realize they are not competitive relative to foreign producers. Other firms may have enhanced incentives to adopt new technologies in their efforts to expand their markets. At the same time, trade openness can be associated with higher volatility of demand shocks facing firms. Also, competition is likely to increase the elasticity of employment to changes in relative prices, including those generated by real exchange rate fluctuations. All of these effects taken together suggest greater factor reallocation. Moreover, since trade reforms in Latin America have also been accompanied by labor 
market reforms intended in principle to make labor adjustment more flexible, the increased incentives for reallocation may be enhanced by reduced adjustment costs.

While it is well beyond the scope of this paper to explore fully the welfare implications of trade and labor market reforms, understanding the reallocation implications of reform is a key component of the welfare implications. One of the most controversial debates on institutional design and economic policy has been sparked around the tradeoffs associated with greater flexibility of product and labor markets. On the one hand, greater flexibility of product and labor markets can imply improved efficiency and productivity as economic forces induce the allocation of resources to their highest valued use. On the other hand, greater flexibility can imply greater uncertainty for workers and firms with associated concerns about job security and wage inequality.

While we do not address these deep welfare and policy questions directly, a step in this direction is to measure the reallocation consequences of reform. In this paper, we take such step by exploiting rich new harmonized statistics on job flows by sector, country and year. In particular, we assess to what extent the increased competition associated with international trade yields increases in the pace of job reallocation within sectors across Latin American countries. During the period of study, many of the countries in our sample underwent substantial real exchange rate movements yielding sectoral variation in trade exposure. But, it is the variation from large tariff declines which differ in their timing across countries that allows us to estimate the response of job flows to intensified international competition. We identify the effect of trade exposure on job flows by studying a set of countries undergoing deep trade liberalization over the sample period.

A unique aspect of our analysis is that we exploit variation in the pace of job reallocation across time at the sectoral level for a number of countries. We use harmonized job flow measures constructed from plant-level data from manufacturing surveys in Argentina, Brazil, Chile, Colombia, Mexico and Uruguay. Much of the cross- 
country evidence on job flows exploits simple cross-country variation or country-year variation. In contrast, we exploit country, year, and sectoral variation. Moreover, we exploit this variation in a policy environment where there have been significant changes in the trade environment along these same dimensions and we have measures of such changes through the changes in tariffs at the country, sector and year level of variation.

The paper proceeds as follows. Section 2 reviews the related literature. In Section 3, an account is provided of international trade institutions in Latin America with special reference to recent episodes of liberalization. Section 4 describes our dataset and discusses the results on the effects of changes in exposure to international trade on job reallocation. Finally, Section 5 concludes.

\section{RELATED LITERATURE}

Traditional trade models predict factor reallocation between sectors. When barriers to international trade are removed, the classical Ricardian argument predicts a redeployment of resources towards sectors with comparative advantage. The HecksherOhlin model would predict expansion of sectors intensive in the relatively abundant factor. The implication of inter-sectoral reallocation is partly driven by the assumption of homogeneity among producers within the same sector. Recent models have explored the impact of openness to international trade when producers face idiosyncratic shocks.

To characterize the impact of trade on aggregate productivity, Melitz (2003) assumes that producers have heterogeneous productivity levels and models intra-industry reallocations among firms when faced with foreign competition. Within industries exposed to trade, increased openness leads to shifts in the relative performances of monopolistic competitors reflected in inter-firm reallocations towards more productive firms. In an alternative model with similar results, Eaton and Kortum (2002) model heterogeneous producers in a perfectly competitive environment. Constant-returns producers are subject to idiosyncratic shocks while consumers search worldwide for 
lowest prices of each output variety. Then, international trade allocates demand to producers able to supply output at the lowest price. Efficient technology (i.e., low production costs), minimal geographic impediments (i.e., low transportation costs) and limited institutional distortions (i.e., low transaction costs) allow producers to price competitively. Both papers predict productivity-enhancing reallocations, within industries, induced by trade. ${ }^{1}$ The notion that protectionism shelters inefficient producers and that openness makes more productive firms flourish is corroborated by the evidence.

Self-selection into export markets by more productive plants is well documented by Clerides, Lach and Tybout (1998) for Colombia, Mexico and Morocco; by Bernard and Jensen (1999a) for the U.S.; and by Aw, Chung and Roberts (2000) for Taiwan. Underlying this process is the existence of substantial sunk costs to enter export markets documented by Roberts and Tybout (1997) for Colombia and by Bernard and Jensen (1999b) for the U.S. Indeed, Hallward-Driermayer, Iarossi and Sokoloff (2002) have argued that the selection process is not necessarily driven by exogenous shocks but rather by investments made by firms in anticipation of foreign markets opening up. Decisions regarding organization, training and retooling to gain access to export markets raise relative exporter productivity in East Asia most significantly in Indonesia, the Philippines and Thailand. Heterogeneity in the performance of different investment strategies leads to trade-induced reallocation.

Trade not only facilitates the expansion of more productive firms but also causes the downsizing of less productive plants. With respect to attrition induced by international trade, Aw, Chung and Roberts (2000) find that exposure to trade forces the exit of the least efficient producers in Korea and Taiwan. Also, Pavnick (2002) finds that market share reallocations contributed significantly to productivity growth following trade liberalization in Chile. Finally, Bernard and Jensen (1999b) find that intra-industry reallocations to higher productivity exporters can explain up to $20 \%$ of productivity growth in U.S. manufacturing. 
There is direct evidence on the impact of international competition on job flows. The evidence from plant-panel data for developed countries is suggestive of more trade exposure leading to intensification of churning and sometimes negative net effects on employment. However, was will be clear below, the results differ substantially across countries and studies. For the U.S., Klein, Triest and Schuh (2003) use establishment panel data to analyze how the pattern of gross job flows is affected by the path of the real exchange rate. They find that changes in the trend of the real exchange rate affect reallocation but not net employment. On the other hand, cyclical variation of the real exchange rate induces changes in net employment mainly via job destruction. In a more recent study, Klein, Triest and Schuh (2004) investigate the joint impact of tariff and real exchange rate changes in the US, with particular reference to NAFTA. The way in which the reduction in tariffs impacted upon job flows is similar to the effect of a shift, inducing appreciation of the currency, in the trend of the real exchange rate path.

In the case of U.S. manufacturing, Gourinchas (1998) studies the exchange rate response gross job flows at the four-digit level using data from the Longitudinal Research Database. He finds that times of appreciation are associated with substantial job churning while times of depreciation display very limited reallocation. In addition, he finds that $10 \%$ depreciation increases employment by $0.3 \%$ in the tradable sectors, mostly due to job creation in import competing industries.

Similarly for the U.S., Goldberg, Tracy and Aronson (1999) found using CPS data that exchange rate movements have a small effect on employment and that job destruction is not substantially affected. For the U.S., Davidson and Matusz (2004) find higher sectoral net exports to be associated with less job destruction and more job creation. Also, Revenga (1992) finds that in the U.S. import competing industries reduce employment overall during currency appreciations. Finally, Campa and Goldberg (2001) find that in the U.S. the labor market adjustment to variations in the real exchange rate is primarily through wages rather than employment. They explain the prevalence of price 
rather than quantity adjustment as the result of the lower labor demand associated with currency appreciation being offset by cheaper imported inputs, including equipment and machinery.

Using French firm-level data, Gourinchas (1999) examines the impact of real exchange variations on gross job flows. He finds that exchange rate appreciations reduce net employment growth as a result of lower job creation and increased job destruction. These patterns imply little additional reallocation as a result of exchange rate fluctuations. By contrast, Bentivogli and Pagano (1999) find for a number of European countries a limited effect from currency value fluctuations on job flows. Divergences in results across countries may be explained by differences in labor market institutions. For example, Burgess and Knetter (1998) find in that in the G-7 countries with the most rigid labor institutions, Germany and Japan, employment is, not surprisingly, insensitive to exchange rates. However, in other countries appreciations appear related to drops in employment.

In terms of cross-country evidence, Wacziarg and Wallack (2004) conduct a study on the extent of inter-sectoral reallocation of labor in the wake of trade liberalization events. They find no evidence of increased reallocation of labor across sectors defined at the 1-digit level, although they find evidence of a small increase in inter-sectoral reallocation using manufacturing data at the 3-digit level of aggregation.

In developing countries undergoing deep financial liberalization, one might expect large reallocation effects given the substantial increase in the exposure to international competition. One important aspect of the reallocation process generated by the removal of barriers to trade relates to the impact on job flows. The literature examining the effect of trade reforms on job flows in developing countries is just emerging. A notable exception is the paper by Levinsohn (1999) that reports evidence from firm-level data during a period of tariff reductions and large swings of the real exchange rate. There is a tremendous amount of job churning in Chile, both in expanding and contracting 
industries, not associated with changes in aggregated employment. Hence, changes in trade exposure yield an effect on gross job flows without a substantial effect on net flows. In view of absence of a significant net employment effect, the results highlight the important role played by both heterogeneity and nonconvexity emphasized by Davis and Haltiwanger (1999) in the case of the U.S.

In the Latin American context, there is new evidence for Argentina, Brazil and Uruguay in the present volume pointing to the importance of intra-industry reallocation and job flows in response to trade reform. Sanchez and Butler (in this volume) document that in Argentina trade liberalization and labor market reforms have facilitated reallocation and creative destruction, whereby inefficient incumbent firms are displaced by more efficient producers. Moreover, more openness has been associated with intensified job churning. Indeed, intra- and inter-sectoral reallocations have enhanced productivity as import tariffs appear to have protected obsolete jobs. Ribeiro et al. (in this volume) study the effect of trade liberalization in Brazil. The authors find that increased openness reduces net employment through increased job destruction, with no effect on job creation. In addition, exchange rate depreciations expand the number of jobs in manufacturing by increasing creation, with no effect on job destruction. Casacuberta, Fachola and Gandelman (in this volume) study the impact of trade liberalization on labor market flows in the Uruguayan Manufacturing Sector. They find that higher international exposure substantially increases job destruction, while moderately increasing job creation. Therefore, lower tariffs are associated with higher gross job flows and lower net job growth.

By and large, the existing literature on tariff and exchange rate response finds effects on gross and net employment flows, although the results differ across countries. Gross job flows generally seem to increase with greater exposure to international competition. Exposure to foreign competition induces substantial labor adjustment with an impact on net employment growth in some cases. 


\section{TRADE RESTRICTIONS AND TRADE LIBERALIZATION IN LATIN AMERICA}

Latin American countries constitute excellent laboratories to analyze the effects of changes in trade policy on job reallocation. Until the mid-1980s, trade policies aimed at keeping sectors protected through high tariffs and import restrictions. Yet, the collapse of economic growth and the high inflation rates in the 1980s eliminated the credibility of the import-substitution model and set the stage for trade opening. In the last twenty years, the countries of this region have profoundly reduced their tariff and non-tariff restrictions, and these changes have been larger than those experienced by developed countries during the same period (World Bank, 1996). This shift was facilitated by the multilateral commitments of the Uruguay Rounds of the GATT, by the signing of bilateral and sub-regional agreements, and by unilateral reforms within countries.

Figure 1 shows the evolution of average tariffs in Argentina, Brazil, Chile, Colombia, Mexico and Uruguay for the periods in which information on job reallocation is available. ${ }^{2}$ A downward trend is visible in all countries. In Chile, trade liberalization started in the late seventies, but it was reversed in the early eighties as a response to a severe economic contraction. After 1985, tariffs fell from $25 \%$ in that year to less than 10\% in the late nineties. In Colombia, tariffs declined from 20\% in 1985 to 7\% by 1994. In Mexico, the signature of NAFTA implied a reduction in tariffs of goods imported from the U.S. and Canada from 5\% to $1.3 \%$. In Uruguay, the change in tariffs was even more pronounced. Tariffs in the manufacturing sector fell from an average of $37 \%$ in 1985 to 13\% in the year 1995. By contrast, the decline in tariffs was slower in Argentina and Brazil. In Argentina, average tariffs declined slowly during the first half of the nineties, only to increase again during the second half of the decade. Similarly, in Brazil, a sharp decline in tariffs in the early nineties, was followed by a progressive increase after 1994. 
An important feature of the liberalization process was the adoption of more uniform tariff structures. Figure 2 shows a marked reduction in the standard deviation of average 2-digit sector tariffs in all countries with the exception of Colombia, where such dispersion fell from 1984 to 1994 . Another way to see this convergence effect is to regress the average yearly change in sector tariffs between the first period and the last period of the sample on initial sector tariff levels. As shown in Table 1, the coefficient of this regression is negative and strongly statistically significant, indicating that sectors that started with higher tariff levels experienced the greatest tariff reductions. Initial tariffs also explain a large share of average yearly tariff changes. In the bivariate regression, initial tariffs explain $61 \%$ of the variance in tariff changes. Once country and sector effects are included, these variables jointly explain $95 \%$ of the average yearly changes in tariffs. Thus, more than being driven by the interests of particular industries, trade liberalization was the results of an overall shift in economic orientation. This is an important consideration in the empirical analysis since it suggests that average sector tariff changes were exogenous to changes in sector employment reallocation. This however, does not eliminate the possibility that sector tariffs are driven by aggregate shocks, which in turn are correlated with sector reallocation.

In the six countries studied, the process of removal of protectionist barriers was accompanied by real exchange rate appreciations (RER). Figure 1 shows the evolution of the real exchange rate (RER) defined as domestic currency per U.S. Dollar, divided by the ratio of domestic to U.S. consumer price index (CPI). The data shows a significant downward trend in the RER of Chile, Mexico and Uruguay. It also shows substantial exchange rate appreciation in Argentina, Brazil and Colombia during the periods in which tariffs declined more rapidly. In the next section, we exploit this large variation in trade policy and real exchange rates to estimate the effect of changes in trade protection on job reallocation. 


\section{EFFECTS OF TRADE ON JOB REALLOCATION}

\subsection{Data description}

Following Davis and Haltiwanger (1999), we define job reallocation (SUM) as the sum of job creation (POS) and job destruction (NEG), and the net change in jobs (NET) as the difference between the two. ${ }^{3}$ In some of our analysis we also use a measure of excess reallocation (EX-SUM). Excess reallocation is defined as the difference between job reallocation and the absolute value of net job creation. ${ }^{4}$ In the absence of heterogeneous job creation and destruction patterns across firms within sectors, excess job reallocation would be zero.

The data used in this paper includes sector information at the two-digit level on nine manufacturing industries for six Latin American countries, during the 1980s and 1990s. The number of years covered differs across countries and range between 7 and 21 years (see Table A.1). We use firm-level data for Argentina, Brazil and Mexico, whereas for Chile, Colombia and Uruguay we use plant-level data. Entry and exit data were available for all countries, with the exception of Argentina and Uruguay. For these two countries we construct job flows using only continuous plants.

Trade policy variables are also gathered using different sources and according to different definitions, which vary somewhat from country to country. For Argentina and Brazil, data on average sector tariffs were obtained from the World Integrated Trade Solution (WITS) a tariff database created by the World Bank and UNCTAD. In these two countries, the data refers to the average Most Favored Nation Rate. ${ }^{5}$ For Mexico, the data were obtained from López-Córdova (2003) and refers to the simple average of tariffs on imports from Canada and the U.S. Since Mexican tariffs on imports from countries outside NAFTA declined only moderately during the period covered in our sample, and imports from North America represent the bulk of all Mexican imports, the evolution of tariffs on Canadian and U.S. commodities is a good measure of the process of trade liberalization in Mexico (see Lopez-Córdova (2003)). For Colombia, tariff data 
were obtained from Medina, Melendez and Seim (2003) and refer to implicit sector tariffs, that is, the ratio of tariff collection to imports per sector. For Uruguay, the data refers to average tariff per sector data and is obtained from Casacuberta et al. (2003). Finally, data on Chile was obtained from Rojas et al (2001), and refers to the average tariff for the whole economy.

Table 2 presents the summary statistics of job flows for industries at the two-digit level for each country and for the whole sample. For the overall sample, employment at the industry level is falling on average at an annual rate of 0.5 percent. This decline is higher than three percent in Argentina and Uruguay, countries undergoing deep recessions during the years covered in this study. The only country with a large expansion in manufacturing employment is Mexico, with at annual rate of $6.8 \%$. Substantial average job growth in Mexico is due to the expansion in manufacturing after the creation of NAFTA as well as the increase in the coverage of the survey used in this study.

Job reallocation is on average $21 \%$, going from a minimum of $4.5 \%$ in "Basic Metal Industries" in 1985 to a maximum of 51\% in "Manufacture of Wood and Wood Products" in 1988, in both cases in Chile. Brazil stands out as the country with the highest job reallocation rates (32\%), while Argentina (14\%) and Uruguay (14\%) have the lowest turnover in our sample because of lack of information on entry and exit in these countries. Colombia is the country with the lowest rates among the sample of countries in which firm entry and exit data are available. Cross-country comparisons, however, should be treated cautiously due to differences in the treatment of entry and exit, in the collection and nature of the data and in the definition and treatment of firm mergers. This is a standard problem in cross-country exercises, which we will be able to avoid by controlling for time, country and sector effects as well as country-specific trends and, in some specifications, for sector-country effects. 
For the whole pooled sample, job creation and destruction are equally important at accounting for the average level of job reallocation. This is not the case for Mexico where job creation accounts for more than 60 percent of its turnover, and for Argentina and Uruguay where job destruction accounts for around 60 percent of job reallocation. Focusing on excess job reallocation (EX-SUM), we observe that for the whole sample and for each country most of sector reallocation is within sector. Aggregate annual employment variations at the two-digit sector level explain only 25 percent of total job reallocation in our sample.

Table 3 shows what fraction of variation in SUM, POS, NEG and NET is accounted for by country effects (row 1), sector effects (row 2) and year effects (row 3). For job turnover, specific country characteristics explain almost half of the SUM variances in our sample. This may reflect different institutional arrangement across countries, like job security and level of openness, or it may reflect differences in data collection and measurement. Interestingly, the high explanatory power of country effect comes mainly from the job creation component of job turnover which suggests that it is not simply driven by measurement factors since the latter are likely to impact both job creation and destruction symmetrically. In fact, the country effect explains 50 percent of the variance of POS but only 17 percent of NEG. Besides country effects, sector characteristics also explain an important fraction of the variance of job turnover in our sample (20\%). Taken together, country and sector effects explain more than 60 percent of the job reallocation variance (15 classes; row 4). This percentage increases to 78 percent when we consider country-sector interactions (54 classes; row 7). This finding that there is substantial additional explanatory power from the interaction of countries and sectors is especially important for the empirical strategy that follows since it indicates that sectors exhibit quite different behavior across countries. Finally, Table 3 shows that year effects account for a minor fraction of the variance of job reallocation $(13 \%)$. 
For net changes in employment (NET), year effects explain the largest fraction of the variance (23\%) suggesting common shocks are quite important in the sectoral variation in net employment growth across countries. Put differently, these results showcase the well-know fact that these economies were commonly affected by the Debt, Tequila, Asian and Russian crises during the 1980s and 1990s. Country-specific effects explain $15 \%$ of the variance, whereas sector effects have modest explanatory power. Taking together the country and year effects (31 classes; row 5) they explain 41 percent of the variance. This increases to $68 \%$, if we consider country-year interactions (90 classes; row 8).

Figure 3 describes the evolution of SUM, NET and average tariffs, at the manufacturing level for the six countries we are studying. ${ }^{6}$ For Argentina and Uruguay, the figure shows a continuous decline in employment in manufacturing, in particular after 1998. The opposite is true for Mexico. After the tequila crises and NAFTA, employment in manufacturing has been growing fast. In particular, during 1996 and 1997 when we observe the rate of job growth at the two-digit level. In Chile, employment growth reflects the business cycle. At the beginning of the sample during the debt crisis, employment fell drastically in the Chilean manufacturing sector. After that, there was a long period of expansion that ended with the Asian crisis of 1997. In 1998 and 1999 (i.e., the time of the Russian Crisis) manufacturing employment fell by more than 15 percent. Colombia shows a stable path until 1997. However, during the Asian crisis, employment fell by 6 and 10 percent in 1998 and 1999, respectively.

At the aggregate manufacturing level over time, job reallocation has been more stable than net changes in jobs. For each country, the aggregate time series variance of NET is more than twice the variance of SUM. We do not observe clear trends in job reallocation for Argentina, Chile and Uruguay. Instead, the data suggests a positive trend in job reallocation in Colombia and Brazil. Finally, in Mexico there is a clear fall in 
turnover after 1997. The average reallocation in the first part of the sample in Mexico is $30 \%$ which falls to less than $25 \%$ after 1997.

In most countries we observe a negative correlation between job turnover and net changes in jobs at the aggregate manufacturing level. This pattern does not hold for Mexico and Uruguay, although in neither of these two cases the correlation between NET and SUM is statistically significantly different from zero. For the two countries in which we have long time-series, Chile and Colombia, there is a clear and statistically significant negative correlation between NET and SUM (see Table 3). This result implies that job destruction is more volatile than job creation and is similar to the one found for the U.S. However, it is not the focus of this paper to focus on the aggregate time series variation.

Figure 1 does not show a systematic correlation between job reallocation and the level of tariffs. For Argentina, Brazil, Mexico and Uruguay, mean tariffs and turnover have a positive correlation, although it is statistically significant at standard level only for Mexico (i.e., at the 10 percent level). For Chile and Colombia this correlation is negative although not statistically significant. These simple aggregate correlations should be treated cautiously since they do not control for contemporaneous changes in other covariates (such as exchange rates). In addition, they do not exploit the variability at the sectoral level. In the next section, we estimate the effect of tariffs and exchange rates on job reallocation making use of sector level data and controlling for other covariates.

\subsection{Empirical strategy}

Our main analysis focuses on the impact of trade reforms on the pace of job reallocation and net employment growth within sectors within each country. For this purpose, we focus on a summary measure of gross job flows - in particular job reallocation. We use overall job reallocation rather than excess job reallocation in this analysis since the latter has some limitations when using high frequency data. That is, if job reallocation takes time such that a change in the economic environment leads to an 
increase in job destruction in one period and an increase in job creation in subsequent periods, the measure of excess job reallocation will not capture such increases in reallocation. ${ }^{7}$

We specify the main job flows (gross job reallocation) and net employment regressions as follows:

$$
\begin{aligned}
& \mathrm{SUM}_{\mathrm{jct}}=\delta \mathrm{SUM}_{\mathrm{jct}-1}+\gamma \operatorname{Tariff}_{\mathrm{jct}-1}+\mathrm{D}_{\mathrm{j}}+\mathrm{D}_{\mathrm{t}}+\mathrm{D}_{0 \mathrm{c}}+\mathrm{D}_{1 \mathrm{c}} \mathrm{t}+\theta \mathrm{JS}_{\mathrm{ct}}+\varepsilon_{\mathrm{jct}}, \\
& \mathrm{NET}_{\mathrm{jct}}=\lambda \mathrm{NET}_{\mathrm{jct}-1}+\beta \operatorname{Tariff} \mathrm{jct}-1_{1}+\mathrm{D}_{\mathrm{j}}+\mathrm{D}_{\mathrm{t}}+\mathrm{D}_{0 \mathrm{c}}+\mathrm{D}_{1 \mathrm{c}} \mathrm{t}+\alpha \mathrm{JS} \mathrm{S}_{\mathrm{ct}}+\eta_{\mathrm{jct}},
\end{aligned}
$$

where $\mathrm{SUM}_{\mathrm{jct}}$ and $\mathrm{NET}_{\mathrm{jct}}$ are job flow (gross job reallocation) and net employment measures in sector $\mathrm{j}$ and country $\mathrm{c}$ and at time $\mathrm{t}$; and $\mathrm{SUM}_{\mathrm{jct}-1}$ and $\mathrm{NET}_{\mathrm{jct}-1}$ are the corresponding lagged values. $D_{j}, D_{t}$, and $D_{0 c}$ are sector, time and country effects, respectively, and the term $\mathrm{D}_{1 \mathrm{c}}$ t captures country-specific trends. Some specifications include a job security measure, $J S_{\mathrm{ct}}$, since job security provisions where changing over the period of study in several of these countries, including Argentina, Brazil and Colombia. Tariff $\mathrm{jct}_{\mathrm{j}-1}$ captures the effect of taxes on imports in sector $\mathrm{j}$ and country $\mathrm{c}$ at time $\mathrm{t}-1$ on job flows and net employment, where the lag of tariffs is included to avoid capturing reverse causality. Thus, while we showed that changes in tariffs were, to a large extent, driven by a change in policy regime, it could still be the case that some sectors affected by job reallocation or employment losses engaged in intense lobbying to protect these sectors.

Equations (1) and (2) are the main specifications but there are likely other factors impacting the pace of job reallocation and net employment growth within sectors even though we have a very rich set of controls (country effects, year effects, sector effects and country-specific trends). For current purposes, our main interest is to explore additional 
factors that may be capturing or related to changes in the trade environment. Thus, we also consider specifications where we include the lagged real exchange rate (RER) as a regressor as follows:

$$
\begin{gathered}
\mathrm{SUM}_{\mathrm{jct}}=\delta \mathrm{SUM}_{\mathrm{jct}-1}+\gamma_{1} \text { Tariff }_{\mathrm{jct}-1}+\gamma_{2} \Delta \% \mathrm{RER}_{\mathrm{ct}}+\mathrm{D}_{\mathrm{j}}+\mathrm{D}_{\mathrm{t}}+\mathrm{D}_{0 \mathrm{c}}+\mathrm{D}_{1 \mathrm{c}} \mathrm{t}+\theta \mathrm{JS}_{\mathrm{ct}}+\varepsilon_{\mathrm{jct}}, \\
\mathrm{NET}_{\mathrm{jct}}=\lambda \mathrm{NET}_{\mathrm{jct}-1}+\beta_{1} \text { Tariff }_{\mathrm{jct}-1}+\beta_{2} \Delta \% \mathrm{RER}_{\mathrm{ct}}+\mathrm{D}_{\mathrm{j}}+\mathrm{D}_{\mathrm{t}}+\mathrm{D}_{0 \mathrm{c}}+\mathrm{D}_{1 \mathrm{c}} \mathrm{t}+\alpha \mathrm{JJ} \mathrm{S}_{\mathrm{ct}}+\eta_{\mathrm{jct}},
\end{gathered}
$$

where $\Delta \% \mathrm{RER}_{\mathrm{ct}}$ is the log first difference in the real exchange rate in country $\mathrm{c}$ between time $t$ and $t-1$. We use the growth rate of the real exchange rate because we are interested in how cyclical real exchange rates affect job flows and net employment. In principle, we would like to use sector-specific exchange rate measures as in Klein et al. (2003), but these are not readily available for our sample of Latin American countries. Given the limitations of the data and concerns about measurement problems, omitted variable or endogeneity biases associated with exploring the role of the exchange rates in specifications with the exchange rate, we also include a number of additional controls. First, because changes in the real exchange rate may be affected by changes in the consumer price index within countries and across sectors, we control for country-sector interactions in these specifications. In addition, since countries have different trends in real wages and labor intensity differs across industries, sectoral trends will be different across countries. Nonetheless, it is worth mentioning that changes in the real exchange rate in our data come mainly from changes in the nominal exchange rate. Second, we control for changes in GDP in these specifications because real exchange realignments may coincide with cyclical changes in the economy which directly affect job reallocation and net employment. Failing to control for changes in GDP, thus, would overestimate the effect of real exchange rates on job reallocation and net employment. 


\subsection{Results}

Table 5 reports the results on job reallocation. Columns (1) and (2) show results of specification (1) with and without job security measures. In all specifications, the coefficients on the lagged value of job reallocation in Table 5 show that job reallocation adjusts slowly, since job reallocation in period $\mathrm{t}$ depends largely on job reallocation during period $\mathrm{t}-1$.

In terms of the main focus of the analysis, the results show that job reallocation decreases as tariffs rise. In particular, a decrease in tariffs of one standard deviation (7.5\%) increases job flows by slightly more than half a percent $(0.6 \%)$ which reflects variation that accounts for about 7 percent of the overall pooled standard deviation of job reallocation

The results are similar whether we include or exclude a job security measure. In terms of the latter, job security has seemingly little effect on job reallocation which is a bit surprising. However, since we are exploiting country, sector, year variation in the job flows and only have country-year variation in job security and also include country, year, sector dummies and country-specific trends as controls, it is likely that we have insufficient variation remaining to capture much of an effect here. A better approach for gauging the impact of job security is likely the approach taken by Micco and Pagés (2004) and Caballero et al. (2004).

Columns (3)-(5) report results including the annual percentage change in the real exchange rate as well. The results show that a fall in the real exchange rate has a similar effect to a tariff reduction, i.e., an appreciation increases job reallocation. In particular, using the coefficients from Column (5) shows that a decrease in the real exchange rate by one standard deviation (11\%) increases job reallocation by almost one percent $(0.9 \%)$. This means that the impact of a cyclical appreciation is similar to that of a tariff reduction, but larger in magnitude, taking into account the respective standard deviations. The results are similar when we include country-sector interactions and when we control 
for changes in GDP. It is also useful to emphasize that the results on the impact of tariffs are quite robust to the inclusion of these other factors like real exchange rates and changes in GDP. That is, the sign, magnitude and significance of the coefficient on tariffs in the job reallocation regressions is quite similar across specifications.

Table 6 reports the results of tariffs and real exchange rates on net employment based on equations (2) and (4). The results are less robust for net employment. For tariffs, the results show that a negative effect of tariffs when we do not control for job security measures, but the effect disappears when we include a job security index in Column (2). Moreover, controlling for country-sector interactions indicates that higher tariffs actually increase employment by protecting many sectors from competition. This latter finding is consistent with the result in the literature that reducing tariffs induces a net contraction in employment, at least temporarily. The implied impact in column 5 is large with a tariff reduction of one standard deviation (7.5\%) yielding a decline in net employment growth of about 1.6 percent. We interpret this latter finding cautiously since the sign and the magnitude of the coefficient on tariff changes is quite sensitive to alternative specifications.

A real exchange rate appreciation has a positive effect on net employment growth, but it is only marginally significant and relatively small in magnitude when including GDP changes (a one standard change in the real exchange rate yields about a half percent change in net employment growth). It is our sense that the larger magnitude of the effects of real exchange rate changes in specifications without GDP changes primarily reflects real exchange rate fluctuations proxying for other cyclical factors. Once we control for such cyclical factors, there is less influence of exchange rates on net employment.

Indeed, the results in Table 6 imply that a currency appreciation is associated with lower net employment. While the estimated coefficient of the real exchange on employment becomes much smaller when GDP growth is controlled for, it still remains 
significant and positive. These results contrast with most of the literature examining the effect of trade exposure on employment. Usually the intensification of international competition is found to generate either lower employment, due to decreased labor demand, or no discernible response from net employment.

The explanation behind the contrasting effects between our results and earlier ones, found mostly in industrialized economies, is that changes in the real exchange rate affect employment in two ways. First, appreciation of the local currency exposes domestic producers to stiffer international competition. The loss of market share yields lower labor demand. Second, currency appreciation makes imported inputs less costly (see e.g., Campa and Goldberg, 2001). Specifically, the price of equipment and machinery goes down. Also, in Latin American countries, there is some evidence that currency appreciation lowers finance costs (see e.g. Galindo, Panizza and Schiantarelli, 2003). As investment rises, labor demand increases. Hence, there are two offsetting effects of appreciation on employment. Labor demand decreases as output falls due to intensified international competition. At the same time, labor demand increases due to job creation associated with capital formation. The latter effect seemingly dominant in our sample is more likely to be important in Latin America than in the U.S. or European countries as there is much more reliance in developing countries on imported capital and external finance.

To sum up, our most robust results are with respect to tariffs, exchange rates and job reallocation. We find that a reduction in tariffs and an appreciation of the real exchange rate increase job reallocation. We find mixed evidence on the impact of net employment from these trade variables. In what might be viewed as our preferred specification (Column (5) of Table 6 which has all controls), we find that a reduction in tariffs is associated with a decline in employment and a real appreciation is associated with an increase in employment. 
Several factors may underlie our less robust results on net employment. For one, year effects and country-specific trends account for a much larger fraction of the variation in net employment growth by themselves so our controls may be capturing a larger fraction of the variation. For another, the literature has found mixed results on net employment growth consistently with the existence of offsetting effects from currency appreciations as highlighted by Campa and Goldberg (2001). Finally, it may be that our controls for other cyclical factors in the net employment growth regressions are inadequate. We know from the analysis of variance that country-year interactions account for a large fraction of net employment growth fluctuations suggesting that finding adequate cyclical controls is especially important for net employment growth.

\section{CONCLUSION}

Understanding the resource allocation consequences of economic reforms is critical for policy evaluation but data limitations have made such evaluation difficult. The recent literature on factor reallocation has emphasized that much of the reallocation of factors across producers in market economies is across producers within sectors rather than between sectors so that the traditional approach of examining the sectoral reallocation consequences of economic reforms potentially misses much of the story.

In this paper, we exploit newly available measures of gross job flows at the country, sector, and year level for Latin American economies. These rich new data are harmonized using closely related datasets and measurement methodologies in the respective countries. Still, even here data limitations suggest that exploiting simply the between country variation is fraught with difficulties so it is especially useful to be able to exploit the variation within countries across sectors. To be clear, we are exploiting the job reallocation within sectors across time within countries but in turn exploiting the variation in such within sector, within country variation across sectors, countries and

time. Our simple analysis of variance suggests that pursuing this approach has 
considerable promise as the evidence suggests that while there are common sector effects in all countries there is substantial explanatory power from the interaction of country and sector effects.

In terms of reforms, we focus our attention on trade reforms. This focus on trade reforms is appropriate in this context for two closely related reasons. For one, much of the reforms in Latin America in the 1980s and 1990s (the time period for our sample) focus on making domestic markets more competitive via trade reform. For another, the trade reforms have potentially differential impacts across sectors as the tariffs themselves vary by sector but also the sensitivity of sectors to trade reforms likely differs across sectors.

We find that trade reforms have significant effects on the pace of job reallocation within sectors. However, the effects are not that large given the magnitude of the changes undergone by the countries during the analyzed period. Lowering tariffs increases the pace of job reallocation which is consistent with the hypothesis that reforms will aid in improving allocative efficiency. However, such improvements are not without costs. For one, reallocation itself is costly. For another, we find some evidence that a reduction in tariffs is also associated with a decline in net employment growth.

The analysis in this paper is only one small step towards policy evaluation of trade reform (or other market reforms) that takes into account the impact of policy on factor reallocation. Several other steps are required including understanding what are the efficiency consequences of factor reallocation (i.e., the extent to which enhanced reallocation from trade reforms is productivity enhancing) and what are the consequences for workers caught up in the increased pace of reallocation. In addition, consideration of an explicit structural model that permits welfare evaluation of all of these issues is required. While all of these steps are well beyond the scope of this paper, the analysis in this paper suggests that developing the data infrastructure that permits this type of analysis and in turn the associated structural models has great promise for future research. 


\section{FOOTNOTES}

1. The difference between the models is that while Melitz endogenizes the range of varieties produced and traded in each country, Eaton and Kortum endogenize the distribution of mark-ups among countries by holding varieties fixed.

2. Tariffs for Colombia are defined as the ratio of tariff collection to total imports. For Mexico tariffs are defined as the average tariffs from goods and services imported from Canada and the US. For the rest of the countries tariff data refer to the unweighted average of tariffs levied on imports from all countries. See section 4 for a detailed list of sources.

3. Job Creation is defined as the sum of employment changes for plants that increase labor between year $\mathrm{t}-1$ and year $\mathrm{t}$, divided by the average total employment in years $\mathrm{t}-1$ and $\mathrm{t}$. Job Destruction is the negative of the sum of employment changes for plants that decrease labor between year $\mathrm{t}-1$ and year $\mathrm{t}$, divided by the average total employment in years $\mathrm{t}-1$ and $\mathrm{t}$. By construction, job destruction is positive.

4. See Davis and Haltiwanger (1999).

5. Unfortunately, such dataset only cover information for the nineties, and it is quite incomplete for some countries, such like Uruguay. To obtain information for those years/countries we had to find alternative sources of tariff data.

6. SUM and NET at the manufacturing level is computed as the two-digit industries average weighted by employment (average employment between $t$ and $t-1$ ). We report the simple average mean Tariff for the manufacturing sector.

7. Put differently, excess job reallocation is a better measure when using averages across time and exploiting cross sectional variation only.

8. Including an aggregate growth measure is consistent with the specification in Klein et al. (2003) who include it as we do as a control variable. They argue that reverse causality is implausible since it is unlikely that sectoral job flows cause GDP. This argument is likely more persuasive in their case since they use 4-digit data. However, we note even in their case that there still may be a problem since common shocks that impact GDP and sectoral job flows make the interpretation of the coefficients on the aggregate growth term difficult to interpret at best. However, like Klein et al. (2003) we regard including the growth of GDP as a useful control in this context. One way to overcome these concerns would be an IV approach. In unreported results, we explored specifications in which GDP changes are instrumented with GDP changes of trade partners, weighting by the relative importance of the trade partners. The results that emerge from these IV specifications are generally quite similar to those that we report here. We do not focus on these IV results since we believe our results using the exchange rate are only exploratory given that we do not have sector-specific exchange rates. In contrast, our tariff measures vary by sector in addition to by country and year so we place greater emphasis and confidence on those results. 


\section{REFERENCES}

Aw, Bee Yan, Dukkyun Chung and Mark Roberts. 2000. "Productivity and Turover in the Export Market: Micro-level evidence from the Republic of Korea and Taiwan (China)," World Bank Economic Review, 14: 65-90.

Bentivogli, Chiara and Patrizio Pagano. 1999. "Trade, Job Destruction and Job Creation in European Manufacturing," Open Economies Review, 78(1): 165-184.

Bergoeing, Hernando \& Repetto. 2003. "Idiosyncratic Productivity Shocks and Plantlevel Heterogeneity,” Mimeo, DEA, Universidad de Chile.

Bernard, Andrew and Bradford Jensen. 1999a. "Exceptional Exporter Performance: Cause, Effect or Both," Journal of International Economics, 47(1): 1-38.

Bernard, Andrew and Bradford Jensen. 1999b. "Exporting and Productivity," NBER Working Paper No. 7135.

Burgess, Simon and Micheal Knetter. 1998. "An International Comparison of Employment Adjustment to Exchange Rate Fluctuations," Review of International Economics, 6(1): 151-163.

Caballero, Ricardo, Kevin Cowan, Eduardo Engel and Alejandro Micco (2004). "Effective Labor Regulation and Microeconomic Flexibility," mimeo M.I.T., March.

Campa, Jose and Linda Goldberg. 2001. "Employment versus Wage Adjustment and the U.S. Dollar," Review of Economics and Statistics, 83(3): 477-489.

Casacuberta, Carlos, Gabriela Fachola and Néstor Gandelman. 2004. "The Impact of Trade Liberalization on Employment, Capital and Productivity Dynamics: Evidence from the Uruguayan Manufacturing Sector," Journal of Policy Reform, this volume.

Clerides, Sofronis, Saul Lach and James Tybout. 1998. "Is Learning by Exporting Important? Micro-dynamic Evidence from Colombia, Mexico, and Morocco," Quarterly Journal of Economics, 113(3): 903-960.

Davidson, Carl and Stephen Matusz. 2004. "Trade and Turnover: Theory and Facts," forthcoming in the Journal of International Economics.

Davis, Stephen and John C. Haltiwanger. 1999. "Gross Job flows.” In Ashenfelter, Orly and David Card, eds., Handbook of Labor economics, Vol. 3B, Amsterdam: Elsevier Science, North Holland, pp. 2711-2805. 
Eaton, Jonathan and Samuel Kortum. 2002. "Technology, Geography and Trade," Econometrica, 70(5): 1741-1795.

Galindo, Arturo, Ugo Panizza and Fabio Schiantarelli (2003), "Debt Composition and Balance Sheet Effects of Currency Depreciation: A Summary of the Micro Evidence," Emerging Markets Review, 4(4): 330 - 9.

Goldberg, Linda, Joseph Tracy and Stephanie Aaronson. 1999. "Exchange Rates and Employment Instability: Evidence from Matched CPS Data." American Economic Review, 89 (2): 204-210.

Gourinchas, Pierre-Olivier. 1998. "Exchange Rates and Jobs: What Do We Learn from Job Flows?" NBER Macroeconomic Manual 1998, MIT Press, Cambridge, MA, pp. 153207.

Gourinchas, Pierre-Olivier. 1999. "Exchange Rates Do Matter: French Job Reallocation and Exchange Rate Turbulence, 1984-1992." European Economic review, 43(7): 12791316.

Hallward-Driermayer, Mary, Giovanni Iarossi and Kenneth Sokoloff. 2002. "Exports and Manufacturing Productivity in East Asia: A Comparative Analysis with Firm-Level Data," NBER Working Paper No. 8894.

Kaplan, Martínez \& Robertson. 2003. "Employment Displacement Costs in Developing Countries: Evidence from Mexico,” Mimeo, ITAM.

Klein, Micheal, Scott Schu and Robert Triest. 2003. "Job creation, job destruction, and the real exchange rate," Journal of International Economics, 59(2): 239-265.

Klein, Micheal, Scott Schu and Robert Triest. 2004. Job Creation, Job Destruction and International Competition. The Upjohn Institute, Washington D.C.

Levinsohn, James. 1999. "Employment Responses to International Liberalization in Chile," Journal of International Economics, 47(2): 321-356.

López-Córdova, Ernesto. 2003. "NAFTA and Manufacturing Productivity in Mexico". Economía, Journal of the Latin American and Caribbean Economic Association, 4(1): 5598.

Medina, Pablo, Marcela Melendez and Katja Seim. 2003. "Productivity Dynamics in the Colombian Manufacturing Sector," Mimeo, Stanford University.

Melitz, Marc. 2003. "The Impact of Trade on Intra-Industry Reallocations and Aggregate Industry Productivity," Econometrica, 71(6): 1695-1726. 
Micco, Alejandro and Carmen Pagés (2004). "Employment Protection and Gross Job Flows: A Differences-in-Differences Approach". IADB Research Department Working Paper 508.

Pavnick, Nina. 2002. "Trade Liberalization, Exit and Productivity Improvements: Evidence from Chilean Plants," Review of Economic Studies, 69(1): 245-276.

Revenga, Anna. 1997. "Employment and Wage Effects of Trade Liberalization: The case of Mexican Manufacturing," Journal of Labor Economics, 15(3): S20-S52.

Ribero, Eduardo, Carlos H. Corseuil, Daniel Santos, Paulo Furtado, Brunu Amorim, Luciana Servo and André Souza. 2004. "Trade Liberalization, the Exchange Rate and Job Flows in Brazil," Journal of Policy Reform, this volume.

Roberts, Mark and James Tybout. 1996. "The Decision to Export in Colombia: An Empirical Model of Entry with Sunk Costs," American Economic Review, 87(4): 545571.

Sanchez, Gabriel and Ines Butler. 2004. "Market Institutions, Labor Market Dynamics, and Productivity in Argentina during the 1990's," Journal of Policy Reform, this volume.

Wacziarg, Romain and Jessica Seddon Wallack (2004), "Trade Liberalization and Intersectoral Labor Movements," forthcoming, Journal of International Economics. 
Table 1: Impact of Initial Tariffs on Average Yearly Changes in Tariffs

\begin{tabular}{lcc}
\hline \hline & $(1)$ & $(2)$ \\
\hline Initial Tariffs & $-.053^{* * *}$ & $-.066^{* * * *}$ \\
& $(0.005)$ & $(0.005)$ \\
Country and Sector & $\mathrm{NO}$ & YES \\
Fixed Effects & & \\
$\mathrm{R}^{2}$ & 0.61 & 0.95 \\
$\mathrm{~N}$ & 60 & 60 \\
\hline \hline
\end{tabular}

Note: $* * *$ indicates coefficient is significant at the 1 percent level. For Chile and Colombia, the initial year is taken to be 1985 . 
Table 2: Descriptive Statistics

\begin{tabular}{|c|c|c|c|c|c|c|c|}
\hline & All Countries & Argentina & Brazil & Chile & Colombia & Mexico & Uruguay \\
\hline SUM & $\begin{array}{c}0.215 \\
(0.083)\end{array}$ & $\begin{array}{c}0.141 \\
(0.033)\end{array}$ & $\begin{array}{c}0.321 \\
(0.042)\end{array}$ & $\begin{array}{c}0.238 \\
(0.085)\end{array}$ & $\begin{array}{c}0.198 \\
(0.055)\end{array}$ & $\begin{array}{c}0.279 \\
(0.068)\end{array}$ & $\begin{array}{c}0.138 \\
(0.042)\end{array}$ \\
\hline Excess SUM & $\begin{array}{c}0.11 \\
(0.053)\end{array}$ & $\begin{array}{c}0.089 \\
(0.032)\end{array}$ & $\begin{array}{c}0.164 \\
(0.032)\end{array}$ & $\begin{array}{l}0.119 \\
(0.07)\end{array}$ & $\begin{array}{c}0.103 \\
(0.042)\end{array}$ & $\begin{array}{c}0.105 \\
(0.041)\end{array}$ & $\begin{array}{c}0.088 \\
(0.043)\end{array}$ \\
\hline POS & $\begin{array}{c}0.162 \\
(0.079)\end{array}$ & $\begin{array}{c}0.096 \\
(0.032)\end{array}$ & $\begin{array}{c}0.279 \\
(0.046)\end{array}$ & $\begin{array}{c}0.166 \\
(0.078)\end{array}$ & $\begin{array}{c}0.159 \\
(0.053)\end{array}$ & $\begin{array}{c}0.201 \\
(0.069)\end{array}$ & $\begin{array}{c}0.089 \\
(0.037)\end{array}$ \\
\hline NEG & $\begin{array}{c}0.105 \\
(0.057)\end{array}$ & $\begin{array}{c}0.053 \\
(0.032)\end{array}$ & $\begin{array}{c}0.158 \\
(0.035)\end{array}$ & $\begin{array}{c}0.119 \\
(0.055)\end{array}$ & $\begin{array}{c}0.095 \\
(0.034)\end{array}$ & $\begin{array}{c}0.174 \\
(0.055)\end{array}$ & $\begin{array}{c}0.05 \\
(0.026)\end{array}$ \\
\hline NET & $\begin{array}{l}-0.005 \\
(0.071)\end{array}$ & $\begin{array}{l}-0.036 \\
(0.045)\end{array}$ & $\begin{array}{l}-0.006 \\
(0.052)\end{array}$ & $\begin{array}{c}0.0 \\
(0.092)\end{array}$ & $\begin{array}{l}-0.008 \\
(0.053)\end{array}$ & $\begin{array}{c}0.068 \\
(0.069)\end{array}$ & $\begin{array}{l}-0.038 \\
(0.057)\end{array}$ \\
\hline Tariff & $\begin{array}{c}0.145 \\
(0.073)\end{array}$ & $\begin{array}{l}0.174 \\
(0.04)\end{array}$ & $\begin{array}{c}0.14 \\
(0.042)\end{array}$ & $\begin{array}{c}0.135 \\
(0.053)\end{array}$ & $\begin{array}{c}0.153 \\
(0.082)\end{array}$ & $\begin{array}{l}0.042 \\
(0.03)\end{array}$ & $\begin{array}{c}0.211 \\
(0.074)\end{array}$ \\
\hline $\begin{array}{l}\text { Real Exchange } \\
\text { Rate }\end{array}$ & $\begin{array}{l}110 \\
(24)\end{array}$ & $\begin{array}{l}108 \\
(8)\end{array}$ & $\begin{array}{l}120 \\
(24)\end{array}$ & $\begin{array}{l}108 \\
(22)\end{array}$ & $\begin{array}{l}108 \\
(18)\end{array}$ & $\begin{array}{c}81 \\
(11)\end{array}$ & $\begin{array}{l}139 \\
(28)\end{array}$ \\
\hline Real Exchange & 0.004 & -0.033 & 0.030 & 0.028 & 0.023 & 0.006 & -0.085 \\
\hline Rate Growth & $(0.109)$ & $(0.098)$ & $(0.155)$ & $(0.021)$ & $(0.062)$ & $(0.160)$ & $(0.038)$ \\
\hline GDP Growth & $\begin{array}{c}0.037 \\
(0.041)\end{array}$ & $\begin{array}{l}0.036 \\
(.055)\end{array}$ & $\begin{array}{c}0.028 \\
(0.021)\end{array}$ & $\begin{array}{c}0.050 \\
(0.051)\end{array}$ & $\begin{array}{c}0.033 \\
(0.025)\end{array}$ & $\begin{array}{c}0.034 \\
(0.042)\end{array}$ & $\begin{array}{c}0.029 \\
(0.032)\end{array}$ \\
\hline $\mathrm{N}$ & 646 & 99 & 72 & 160 & 189 & 63 & 63 \\
\hline
\end{tabular}

For each variable the first row present the average and the second, in parenthesis, the standard deviation. 
Table 3: Analysis of Variance for Pooled Data

\begin{tabular}{lcccc}
\hline \hline & SUM & POS & NEG & NET \\
\hline Country Effects & 0.47 & 0.49 & 0.17 & 0.15 \\
Sector Effects & 0.2 & 0.12 & 0.13 & 0.02 \\
Year Effects & 0.13 & 0.13 & 0.22 & 0.23 \\
Country and Sector Effects & 0.68 & 0.62 & 0.29 & 0.17 \\
Country and Year Effects & 0.51 & 0.55 & 0.37 & 0.41 \\
Sector and Year Effects & 0.33 & 0.25 & 0.35 & 0.25 \\
Country-Sector Interactions & 0.78 & 0.7 & 0.36 & 0.21 \\
Country-Year Interactions & 0.58 & 0.66 & 0.58 & 0.68 \\
Variance & 0.007 & 0.006 & 0.003 & 0.005 \\
\hline \hline
\end{tabular}

Notes: The variance reports the job flows variances in our sample. 
Table 4: Time Series Correlations

\begin{tabular}{|c|c|c|c|c|c|c|}
\hline & Argentina & Brazil & Chile & Colombia & Mexico & Uruguay \\
\hline SUM and NET & -0.024 & -0.019 & $-0.49 *$ & $-0.553 *$ & 0.258 & 0.388 \\
\hline SUM and Average Tariff & 0.009 & 0.104 & -0.277 & -0.361 & $0.706^{*}$ & 0.446 \\
\hline NET and Average Tariff & $0.577 *$ & -0.187 & $-0.682 *$ & 0.051 & -0.205 & $0.946^{*}$ \\
\hline
\end{tabular}

Notes: SUM and NET represent job reallocation and net changes at the manufacturing level, respectively. Average Tariffs are calculated for the entire manufacturing sector. * indicates 
Figure 1

\section{Evolution of Tariffs and Real Exchange Rates in Six Latin American Countries}
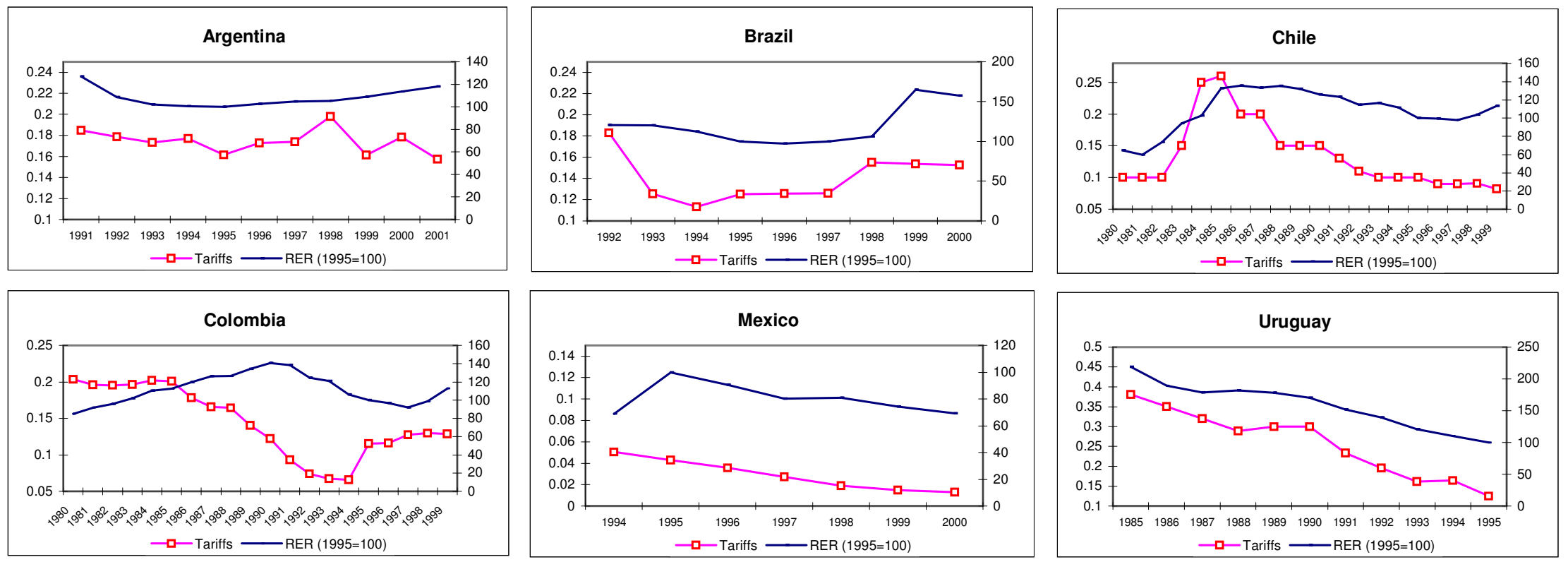

Data from IMF, WorldBank, and other sources. See Section 4 for a detailed list of sources. 


\section{Figure 2}

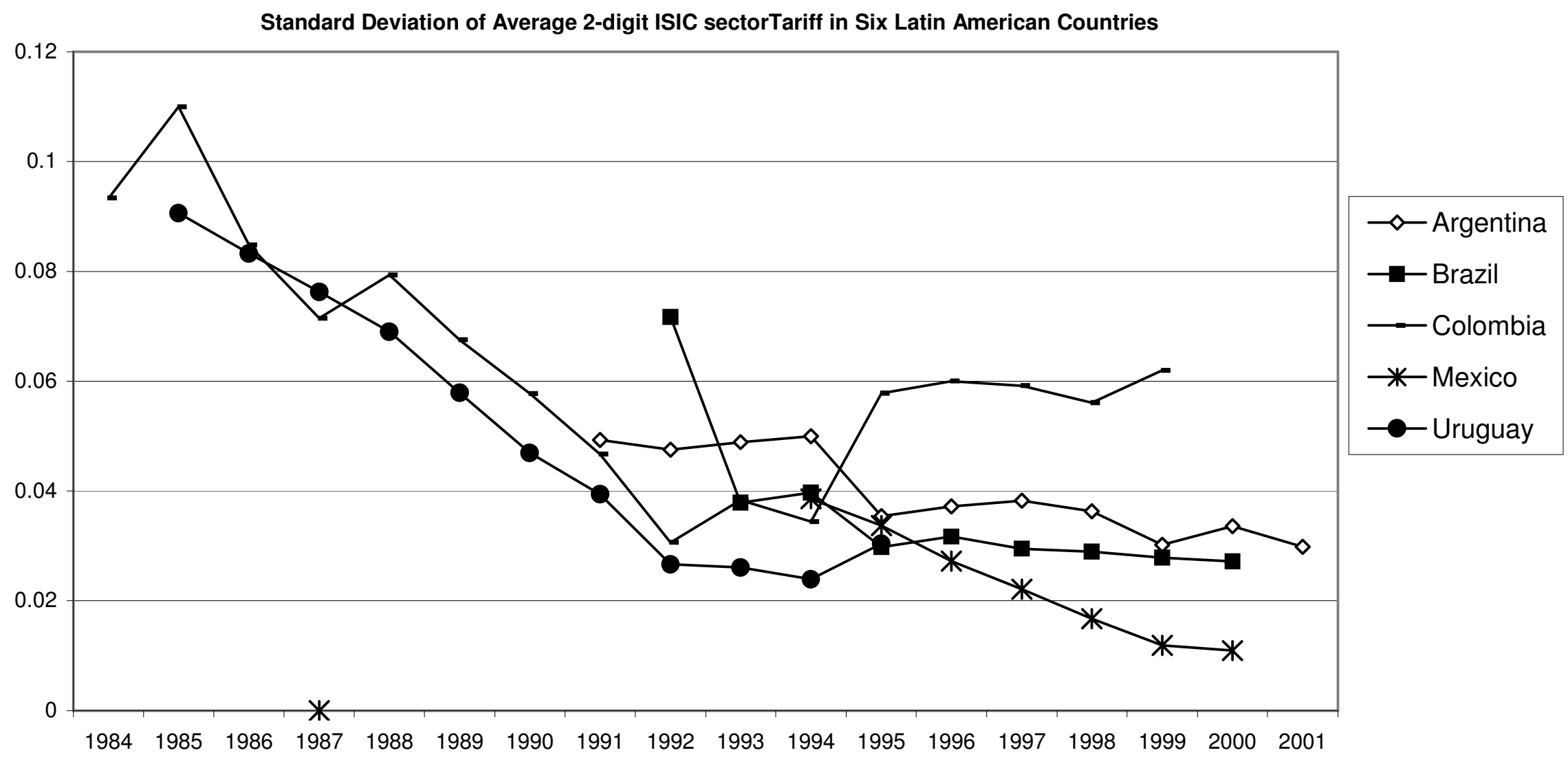

Note: See data sources and description in text. 
Figure 3: Job Flows Dynamics
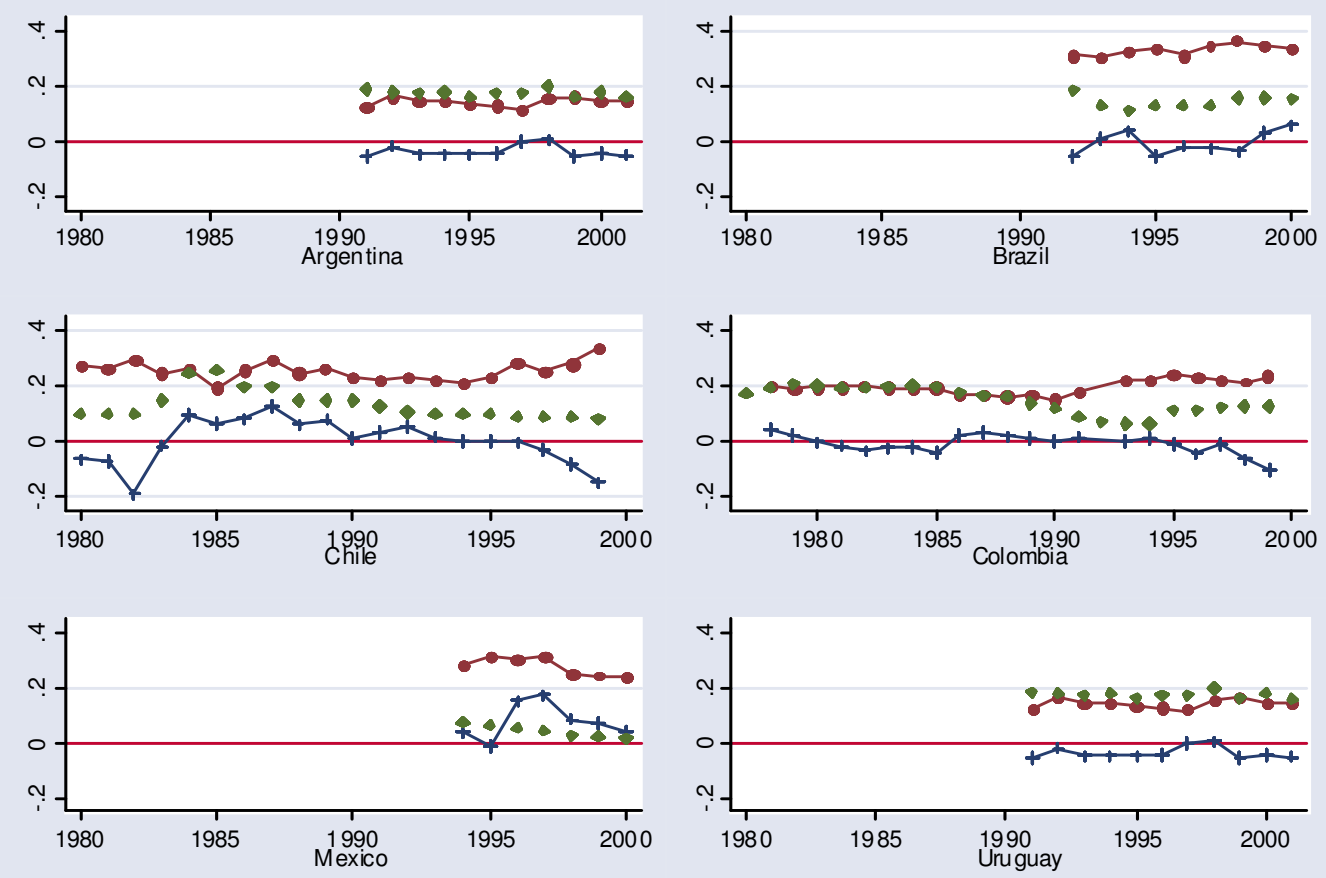

-+- Net change in job

- - job reallocation

- Mean Tariff 
Table 5: Effects of Tariffs and Exchange Rates on Job Reallocation

\begin{tabular}{|c|c|c|c|c|c|}
\hline & $(1)$ & $(2)$ & (3) & $(4)$ & $(5)$ \\
\hline Lagged Job Reallocation & $\begin{array}{c}0.559 * * \\
(0.043)\end{array}$ & $\begin{array}{c}0.56^{* * * *} \\
(0.043)\end{array}$ & $\begin{array}{c}0.555^{* * * *} \\
(0.043)\end{array}$ & $\begin{array}{c}0.258 * * * \\
(0.046)\end{array}$ & $\begin{array}{c}0.257 * * * \\
(0.046)\end{array}$ \\
\hline Lagged Tariff & $\begin{array}{c}-0.082 * * \\
(0.036)\end{array}$ & $\begin{array}{l}-0.074^{*} \\
(0.037)\end{array}$ & $\begin{array}{c}-0.071 * \\
(0.037)\end{array}$ & $\begin{array}{c}-0.089^{*} \\
(0.052)\end{array}$ & $\begin{array}{c}-0.088^{*} \\
(0.052)\end{array}$ \\
\hline Job Security Index & - & $\begin{array}{c}0.0 \\
(0.011)\end{array}$ & $\begin{array}{l}-0.001 \\
(0.001)\end{array}$ & $\begin{array}{r}-0.004 \\
(0.01)\end{array}$ & $\begin{array}{c}0.0 \\
(0.01)\end{array}$ \\
\hline $\begin{array}{l}\text { Change in Real Exchange } \\
\text { Rate }\end{array}$ & - & - & $\begin{array}{c}-0.06 * * * \\
(0.02)\end{array}$ & $\begin{array}{c}-0.068 * * * \\
(0.018)\end{array}$ & $\begin{array}{c}-0.083 * * * \\
\quad(0.02)\end{array}$ \\
\hline Change in GDP & - & - & - & - & $\begin{array}{l}-0.141 * \\
(0.077)\end{array}$ \\
\hline Country-Sector Interactions & NO & NO & NO & YES & YES \\
\hline $\begin{array}{l}\mathrm{R}^{2} \\
\mathrm{~N}\end{array}$ & $\begin{array}{c}0.828 \\
585\end{array}$ & $\begin{array}{c}0.828 \\
576\end{array}$ & $\begin{array}{l}0.83 \\
576\end{array}$ & $\begin{array}{c}0.868 \\
576\end{array}$ & $\begin{array}{c}0.869 \\
576\end{array}$ \\
\hline
\end{tabular}

Notes: All regressions include country effects, year effects, sector effects and country-specific trends. Standard errors are in parenthesis. The job security measure comes from Heckman and Pages (2000). Tariff and real exchange rate data come from the IMF, World Bank, and individual countries. 
Table 6: Effects of Tariffs and Exchange Rates on Net Employment

\begin{tabular}{|c|c|c|c|c|c|}
\hline & $(1)$ & $(2)$ & $(3)$ & $(4)$ & $(5)$ \\
\hline Lagged Job Reallocation & $\begin{array}{l}0.268^{*} \\
(0.052)\end{array}$ & $\begin{array}{c}0.213 * * * \\
(0.058)\end{array}$ & $\begin{array}{c}0.182 * * * \\
(0.057)\end{array}$ & $\begin{array}{c}0.09 \\
(0.059)\end{array}$ & $\begin{array}{c}0.072 \\
(0.054)\end{array}$ \\
\hline Lagged Tariff & $\begin{array}{c}-0.079 * * \\
(0.049)\end{array}$ & $\begin{array}{l}-0.017 \\
(0.051)\end{array}$ & $\begin{array}{l}0.024 \\
(0.05)\end{array}$ & $\begin{array}{c}0.236 * * * \\
(0.085)\end{array}$ & $\begin{array}{c}0.234 * * * \\
(0.079)\end{array}$ \\
\hline Job Security Index & - & $\begin{array}{l}0.048 * * * \\
(0.016)\end{array}$ & $\begin{array}{l}0.051 * * * \\
(0.017)\end{array}$ & $\begin{array}{c}0.042 * * \\
(0.01)\end{array}$ & $\begin{array}{c}0.02 \\
(0.015)\end{array}$ \\
\hline $\begin{array}{l}\text { Change in Real Exchange } \\
\text { Rate }\end{array}$ & - & - & $\begin{array}{c}-0.119 * * * \\
(0.033)\end{array}$ & $\begin{array}{c}-0.132 * * * \\
(0.032)\end{array}$ & $\begin{array}{l}-0.05^{*} \\
(0.027)\end{array}$ \\
\hline Change in GDP & - & - & - & - & $\begin{array}{c}0.827 * * * \\
(0.117)\end{array}$ \\
\hline Country-Sector Interactions & NO & NO & NO & YES & YES \\
\hline $\mathrm{R}^{2}$ & 0.552 & 0.561 & 0.573 & 0.609 & 0.655 \\
\hline $\mathrm{N}$ & 585 & 576 & 576 & 576 & 576 \\
\hline
\end{tabular}

Notes: All regressions include country effects, year effects, sector effects and country-specific trends. Standard errors are in parenthesis. The job security measure comes from Heckman and Pages (2000). Tariff and real exchange rate data come from the IMF, World Bank, and individual countries. 
Table A.1: Job Reallocation Data Sources

\begin{tabular}{lcclll}
\hline \hline Country & Period & Sectors & Unit & Entry/Exit & Source \\
\hline \hline Argentina & $1991-2001$ & 9 & Firms & No & Butler and Sanchez (2004) \\
Brazil & $1992-2000$ & 8 & Plants & Yes & Ribeiro et al (2004) \\
Chile & $1980-1999$ & 8 & Plants & Yes & Bergoeing, Hernando \& Repetto (2003) \\
Colombia 1 & $1978-1999$ & 9 & Plants & Yes & Medina, Meléndez \& Seim (2003) \\
Mexico & $1994-2000$ & 9 & Plants & Yes & Kaplan, Martínez \& Robertson (2003) \\
Uruguay 2 & $1989-1995$ & 9 & Plants & No & Casacuberta, Fachola \& Gandelman (2004) \\
\hline \hline
\end{tabular}

Notes: All information is restricted to the manufacturing sector. Industries are defined using 2 dig. ISIC rev2 classification.

For Brazil and Mexico the data comes from the social security agencies; for the other four countries data comes from Manufacturing Surveys.

1 Due to methodology changes in 1992, we drop this year.

2 We do not use data prior to 1989 due to changes in the methodology and coverage of the survey. 